\title{
Counting Women's Ballots
}

On August I 8, I920, Tennessee became the thirty-sixth state in the union to ratify the Nineteenth Amendment to the United States Constitution. After a more than seventy-year battle, women throughout the United States secured the right to vote. The national enfranchisement of women represented the largest expansion of the electorate in American history, nearly doubling the size of the voting age population. ${ }^{\mathrm{I}}$ Millions of citizens who had never cast a ballot became eligible to do so.

This dramatic expansion of the electorate generated a great deal of activity and uncertainty. Newspapers offered advice to new female voters. "You Can't Drag Your Husband Into The Booth When You Vote on Tuesday!" explained the Bridgeport Post (Bridgeport, CT), helpfully adding that "There Are No Mirrors Inside ... Hubby Cannot Legally Offer You a New Hat to Vote for His Candidate."2 Political parties and women's organizations designed "play elections" and practice voting booths to teach women how to fulfill their new civic obligations. ${ }^{3}$ Cities

\footnotetext{
r We say "nearly" because eleven states allowed women to vote in the I9I6 presidential election. On the other hand, restrictive interpretations of registration rules (ratification occurred after registration deadlines in a number of states) denied women access to the ballot in Arkansas, Georgia, Mississippi, and South Carolina in I920, delaying women's participation in presidential elections in those states until I924 (Gosnell I930). Together with black men, many black women continued to experience systematic exclusion from the franchise until the second half of the twentieth century.

2 "You Can't Drag Your Husband Into The Booth When You Vote Tuesday!" Bridgeport (CT) Post, October 3I, I920. See also: "What the Woman Citizen Should Know" (repeated column). St. Paul Dispatch, July 24, I920, p. 2; “To Women: Register!” Chicago Tribune, August 2 I, I920, p. I.

3 "Play Election Devised to Teach Women How to Vote." Boston Globe, August Io, I920, p. 2; "Women Taught How to Run an Election." Boston Globe, August I3, I920,
} 
and states extended registration times; added days for women to register; and shifted women's names from earlier, limited vote lists, all in an effort to accommodate new female voters. ${ }^{4}$

Expectations were high that women would play a key role in the election. "Women Take the Ballot Seriously" declared one headline just days after ratification. "Registration of Women Is Heavy" advised the St. Paul Dispatch as the election approached. "Women Filled Lines at Every Voting Booth" proclaimed a Boston Globe front-page headline on election day.7 Suffrage leaders predicted a "marked change because of women's entrance into the electorate." 8

Both political parties actively sought the support of new female voters (Bagby 1962; Barnard I928a, b; Jensen I981; Lemons I973). 9 Yet, all of these new voters were apparently a source of considerable anxiety for political organizers: "Women's Vote Baffles Politicians' Efforts to Forecast Election" warned one newspaper headline. ${ }^{\text {Io }}$ The Boston Globe reported that "anxious politicians of both parties are sitting up nights worrying about [women's votes]" in an above-the-fold, front-page article entitled "How Will the Women Vote?" II

Almost roo years later, that question - How did newly enfranchised women vote? - remains to be answered satisfactorily. The decades-long struggle for women's suffrage involved conflicting claims about whether and how women might cast their ballots if permitted to do so. Although the experience of female voters in early enfranchising states had provided some clues, the national enfranchisement of women brought about by the Nineteenth Amendment provided the opportunity to evaluate the electoral behavior of women conclusively. Yet, our knowledge of how

p. 2; "Women Learn How to Vote at Fair." St. Paul Dispatch, September 6, I920, p. 5;

"Registration Week Begins Tomorrow." The New York Times, October 3, I920, p. 4.

4 For example: "Mayor Extends Time for Registration.” Boston Globe, August I9, I920;

"Wednesday Only Day for Women to Get Votes." Chicago Tribune, August 20, I920,

p. 3; "Women Now Registered Stay on Lists." Bridgeport Post, September 22, I920, p. I.

5 "Women Take the Ballot Seriously." Boston Globe, September 8, I920, p. I.

6 "Registration of Women Is Heavy." St. Paul Dispatch, October 23, I920, p. I.

7 "Women Filled Lines at Every Voting Booth." Boston Globe, November 2, I920, p. I.

8 "Women Transforming Polls, Says Mrs. Catt After Vote for Cox." Minneapolis Morning Tribune, November 3, I920, p. 3.

9 For example, “Democrats Lay Plans to Snare Women's Votes.” Chicago Tribune, August IO, I920, p. 7.

10 “Women's Vote Baffles Politicians' Efforts to Forecast Election." Bridgeport Post, October 29, I920, p. I.

II “How Will the Women Vote?” Boston Globe, September 5, I920, p. I. 
women first voted and with what consequence remains contradictory and incomplete.

Two somewhat conflicting sets of conclusions characterize current understandings of the behavior and impact of the first female voters. One perspective emphasizes the failure of women to employ their new right distinctively and of women's suffrage to effectuate any meaningful political change. In this assessment, women took up their right to vote in only very limited numbers, and those who did cast ballots voted just as men did. As a result, the impact of female voters on American politics was virtually nonexistent. As early as I924, writers were asking, "Is Woman-Suffrage a Failure?” (Russell I924; see also Blair 1925; Rice and Willey I924; Tarbell I924), and that characterization was soon accepted as scholarly wisdom (Alpern and Baum I985).

Other scholars, however, have claimed that in some elections and in some places, women exercised their new right in ways distinctive from those of long-enfranchised men. Women have been implicated as major contributors to the Republican landslide of I920, and many have concluded that women's suffrage initially benefited Republican candidates (e.g., Brown I991; Lane 1959; Smith I980; Willey and Rice I924). An association of women with the Progressive movement led many to expect women to be particular supporters of Progressive causes and candidates, such as third-party presidential candidate Robert La Follette in I924 (e.g., Allen I930; Flexner 1959; Ogburn and Goltra I9I9; Russell I924; Tarbell 1924). Others describe women - mobilized by issues of religion and prohibition - as playing a particularly important role in the presidential election of 1928 (Andersen 1996; Burner 1986; Burnham I980; Matthews I992; Sundquist I983). Still others have proposed and uncovered data consistent with the claim that men and women followed distinct paths to New Deal realignment in the I930s (Andersen I979; Gamm I986).

Yet, the evidentiary basis for any conclusions about women's electoral behavior and impact after suffrage turns out to be surprisingly thin. The reason is that we actually possess very limited useful data on how women voted after suffrage. With rare exceptions, official records report only the total number of votes cast overall and for each candidate. Whether women cast ballots, for which candidates, and with what consequences cannot be determined directly from the vote record alone. Reliable public opinion polls - the modern solution to this problem - were virtually nonexistent during this period. Early researchers attempted to draw conclusions from the available aggregate election and census records, 
but since Robinson (I950) social scientists have understood the dangers of what is known as the ecological fallacy (see Chapter 4) and generally shied away from such analysis. Meticulous empirical work has told us something about how women voted in a few places at a few times (e.g., Andersen 1994; Gamm I986; Goldstein I984), but this timeand effort-intensive research is limited both geographically and temporally. As a consequence, more than ninety years after women won the right to vote, and despite a conventional wisdom that can sound quite confident in its conclusions, we actually know far less than we should, or than we believe we do, about the behavior and impact of female voters in the period after suffrage.

This book seeks to fill this lacuna and in doing so, to deepen and improve our understanding of an important period in American electoral history and political development. The enfranchisement of women, the largest expansion of the electorate in American history, transformed the relationship between women and the state (Andersen I996). The extension of suffrage rights to women is a key example of the sort of "durable shift in governing authority" (Orren and Skowronek 2004, I23) that shapes the path of American political development by disrupting and transforming relationships of influence and power. Yet, our current knowledge of how women employed the vote once won remains quite limited, almost roo years after the fact.

Combining unique historic election data and recent methodological innovations, we are able to estimate the turnout and vote choice of new female voters in the five presidential elections following suffrage (1920-1936) for a larger and more diverse set of places - a sample of ten American states - than has previously been possible. This is a major accomplishment. Previous studies were limited to a small number of places over one or a small number of elections. Estimating how particular groups behave based on the available aggregate data on population characteristics and overall election returns has long been considered an insurmountable methodological challenge, particularly for a group as evenly distributed across locales as women are. Our ability to generate reliable estimates of women's turnout and vote choice during this era is a central contribution of this research.

These estimates permit us to observe and evaluate the behavior and impact of new female voters. In doing so, we consider the accuracy of the traditional and often conflicting narratives of the behavior and impact of new female voters found in contemporary and scholarly 
sources. Moreover, we place those long-standing accounts within the context of more general expectations about the turnout and vote choice of women as newly enfranchised citizens derived from elections and voting research. The result is a thorough and extensive theoretical and empirical accounting of the incorporation of women into the American electorate.

While highlighting the contributions we are able to make, we also acknowledge important limitations. Women, like men, are not an undifferentiated bloc in any sense, including politically. A number of characteristics, such as class, ethnicity, immigrant status, and race, surely shaped women's political experiences and incorporation into the electorate. Our methodological approach permits us to offer insights into the electoral behavior of women in general during this period, but it does not allow us to reach any conclusions about the electoral behavior of women in different social groups.

We recognize that different groups of women very likely had different opportunities and propensities to take advantage of their newly granted right to vote. To use one particularly important example, we have every reason to expect that the myriad formal and informal institutions that kept black men from the polls in the I920s and I930s certainly barred most black women from participating as well, despite their concerted attempts to do so. Black women faced particularly strong barriers in the South, where the vast majority of African Americans resided in the I920s and I930s (Lebsock 1993; Terborg-Penn I998). Our data cannot tell us the race of those women who did turn out to vote, but everything we do know about the period leads us to expect there were few African American women in their ranks. Thus, while our data and estimates can only speak of the electoral behavior of male and female voters in general, we are cognizant of the fact that any description of women as an undifferentiated whole masks important variation among and between them. We seek to be attentive to these dynamics when discussing turnout and vote choice in our various states.

In this introduction we first review current understandings of the impact of women's suffrage on American politics. We then turn to a discussion of expectations for the mobilization - both overall and by particular political parties - of newly enfranchised women. Next, we argue for a broader and more nuanced standard for evaluating the contribution of women to elections after suffrage. Finally we preview our findings and map out our plan for the rest of the book. 


\section{The Supposed Impact of Women's Suffrage}

This book inquires into the behavior and impact of female voters after suffrage. For many, these are settled, and easy to answer, questions. Women were initially (and for quite some time) reluctant to turn out to vote. When they did vote, women cast ballots that were largely indistinguishable from those of long-enfranchised men. These claims emerged almost immediately after women won the right to vote (see Alpern and Baum I98 5; Andersen I996; Baker I984). Contemporary writers debated whether, in what ways, and to what extent women in politics were a "failure" (Blair I925; Russell I924; Tarbell I924), while in a widely cited study, scholars described women's "ineffective use of the vote" (Rice and Willey I924). By the I930s, the standard textbook on American politics, Ogg and Ray's Introduction to American Government, could report that the experience of female voters had clearly revealed that "women voters are strikingly like men voters" (I932, II2). These early, largely impressionistic accounts became the basis of the conventional wisdom as "[m]any conclusions drawn in the I920s were incorporated into standard histories of the impact of the adoption of the Nineteenth Amendment" (Alpern and Baum I985, 45).

Indeed, many contemporaries and later scholars concluded not only that the enfranchisement of women had no discernible impact on elections, but that women's suffrage had no impact on politics at all. That is, the belief that women's suffrage was a "failure" described not only elections, but also effects on public policy, politics more generally, and the cause of greater equality for women (see Andersen I996; Baker I984). Despite women's extensive activism in the Progressive movement, women's suffrage failed to generate more reform-oriented and female-friendly public policy. Despite women's supposed natural purity and morality, women's suffrage failed to transform the corrupt world of politics. Despite the great promise of the vote as the sine qua non of democratic politics, women's suffrage failed to dramatically empower women or fundamentally challenge their unequal position in American society.

The "women's suffrage as failure" conventional wisdom has been challenged on a number of fronts. Cott (I990) argues cogently that looking for dramatic political change in the wake of women's enfranchisement ignores the extent and ways in which women were politically active both before and after the "great divide" of I920. Goss (2013) shows how the conventional narrative of women's organizational collapse after suffrage misses the ways in which women's organizational activism diversified in 
the I920s and the degree to which women's advocacy continued apace. As women were already active and influential within movements and as advocates for policy change before enfranchisement (see Clemens I997; Wilkerson-Freeman 2003), we should not expect to see dramatic change when the - one could argue, relatively less powerful - act of casting ballots was added to women's available repertoire of political action (see Pateman I980). Cott (I990, I 53) also challenges electoral impact as the standard by which women's political influence should be judged: "Concentrating on suffrage and the electoral arena means viewing women's politics through the conventional lens where male behavior sets the norm." Many writers, both at the time and since, have emphasized that most politically active women of the period explicitly rejected any expectation of a female voting bloc, arguing instead that women, as diverse and independent human beings, rather than a gendered class, would be similarly diverse in their political choices (e.g., Alpern and Baum I985; Cott I990; McConnaughy 2013; Roosevelt 1940).

Others argue that the failure claim ignores important achievements. At the national level, scholars have credited women's suffrage with providing the impetus for a number of important bills in the early I920s, most notably the Shepard-Towner and Cable Acts pertaining to maternity and infant care and women's citizenship, respectively (Andersen I996; Ogg and Ray 1932). These successes and the general dearth of other new policies responsive to women must be viewed, Andersen (1996) argues, within the broader context of the I920s, a decade of conservative retrenchment and Progressive movement weakness. At the state and local levels, legislators initially responded to women's enfranchisement with various reform policies, many aimed at women and children, and women's suffrage often translated into political influence and activism in complex and important ways (e.g., Schuyler 2006; Scott I972; Wilkerson-Freeman 2003).

Moreover, whatever the direct impact on elections, policy, and politics, the passage of the Nineteenth Amendment transformed women's contested relationship to the political sphere, as well as the "boundaries between male and female" (Andersen 1996, I 5). As we discuss in detail in Chapter 2, by granting women access to the ballot, the Nineteenth Amendment clearly recognized women as political actors in their own, independent right, challenging long-held norms about the appropriate place of women and the nature of politics itself (DuBois I978). Women's suffrage was thus a key step in a long, not always straightforward process of expanding political equality for women. 
We certainly endorse the unambiguous evidence that women acted politically and affected political outcomes long before, and after, the extension of suffrage rights. We also agree that suffrage represented a fundamental transformation of women's relationship to and place within American politics. What remains less well understood is how and with what consequences women exercised their new rights - that is, how women actually voted. Whatever indirect impact enfranchisement might have had, at its core, suffrage transformed women into voters - or at least eligible voters - and thus our knowledge of the impact of women's suffrage remains far from complete.

Women won the right to vote at a time of great transition in American politics. The I920 election, the first after the end of World War I, was heralded as a "return to normalcy" and the decade of the I920s is often viewed as a relatively tranquil and prosperous interlude between two world wars and before the Great Depression. Yet this apparent lull masks a great deal of change and disruption. Electoral participation, historically high and widespread in the late nineteenth century, fell dramatically in the early twentieth century (cf. Burnham I965; Converse I972; Rusk 1974). A third-party presidential candidate garnered 17 percent of the vote in I924, signaling a growing dissatisfaction with the options offered by the two major parties (Rosenstone, Behr, and Lazarus I996). Throughout the decade, new lines of cleavage and an evolving population were transforming the political parties. By I 928 - just the third presidential election after the ratification of the Nineteenth Amendment - the process of what would become known as New Deal realignment was underway, dramatically disrupting previous electoral patterns and ultimately resulting in a dominant Democratic majority after decades of Republican ascendancy.

What did women's suffrage contribute to these developments? Did women - as new and inexperienced voters - contribute to electoral instability and change? Did particular issues and parties mobilize women and attract their votes? Were women - undermobilized and with presumably weaker partisan ties - at the forefront of New Deal realignment? Or, as many have claimed, did women's votes have little or no impact at all? In other words: Did women's votes count?

Our challenge to the suffrage-as-failure narrative is thus found not (only) in the electoral data we analyze, but also in the questions we ask. A misguided focus on suffrage success or failure can obscure many interesting and relevant questions about the experience of female voters in the first elections after suffrage. The behavior and impact of newly enfranchised women is, we argue, best understood in terms of 
mobilization: the decision to turn out (mobilization into the active electorate) and the decision to cast a ballot for a particular party's candidate (mobilization by and into particular parties). Both choices defined women as political actors - turnout made women voters, and vote choice made women active partisans. Both decisions were shaped by women themselves - their interests, characteristics, and experiences. Both choices also were shaped by the political context in which women entered the eligible electorate - the ways in which communities facilitated and/or discouraged women's political engagement and preferences. Both choices are intertwined: People turn out to vote largely to (or because they have been encouraged to) cast ballots for particular parties and candidates: "Deciding whether to vote is a choice made not in the abstract, but in the context of particular candidate choices, party images, and issue agendas" (Andersen I996, 74). Jointly, both kinds of mobilization determine impact. The effect of any group of voters is a function of the mobilization of that group, overall and for particular parties, relative to the mobilization of other groups. Thus, our expectations for the electoral behavior and impact of women after suffrage are shaped by the characteristics of newly enfranchised women themselves and the varying political contexts in which women first had the opportunity to exercise their new suffrage rights.

In the next two sections, we discuss expectations for the mobilization of female voters overall (turnout) and for particular parties (vote choice), respectively. We then return to the question of the impact of women's suffrage, arguing that examining turnout and vote choice together allows us to provide more nuanced evaluations of the contributions of women in the first elections in which they were eligible to participate.

\section{The Turnout of New Female Voters}

One direct impact of women's suffrage has been universally acknowledged: Overall turnout declined as a result of adding women to the eligible electorate. What remains unsettled is how much of the decline in turnout in the early twentieth century can be attributed to women. According to many observers and scholars, women's failure to embrace their new right played a major role. As a population without electoral experience and burdened by strong norms discouraging participation, it is not surprising that women are implicated in many of the major treatments of declining turnout at the turn of the last century (e.g., Converse I972; Rusk I974). According to Converse (I972, 276), 
"while definitive research on the precise effects of female suffrage remains to be done," women's suffrage unambiguously played a (or even the) major role.

There is in fact no question that women initially turned out at lower rates than did men, which, given the size of the eligible female electorate, certainly dampened turnout rates (Andersen I996; Burnham I980; Dugan and Taggart 1995). Yet, others have challenged the assumption that all or most of the I92os decline in turnout can be attributed to new female voters, noting the many factors that discouraged participation more broadly during the period, including widespread one-partyism and the introduction of increasingly restrictive registration rules (e.g., Cott I990; Kleppner I982b). Burnham (1965) points out that much of the early twentieth-century decline in turnout occurred before I920, suggesting that other factors were driving the long-term trend. Similarly, Kleppner (I982b) argues that turnout patterns are not consistent with a hypothesis that women's suffrage was the dominant cause in the I920s, but rather point to the impact of factors such as declining party competition. Andersen (I990) notes that the "System of I896" produced a large number of citizens with weaker-than-usual partisan attachments, also contributing to decreased turnout. Finally, a focus on women's low turnout per se ignores the more complicated effects of women's suffrage in tandem with other long-term shifts in American political culture. The introduction of the Australian (secret) ballot, combined with the shift in polling locations from saloons and barber shops to schools and churches, transformed election day from a raucous, social, and largely masculine spectacle to a placid, bureaucratic proceeding (see Edwards I997). It is perhaps not surprising that these changes were associated with decreased turnout (see Andersen I990; Baker 1984).

Although it is clear that women's turnout initially (and indeed for decades) lagged that of men, basic features of women's mobilization - the level of turnout; the difference in turnout between men and women; and in particular, the variation in the turnout level and gender gap over time and across space - remain largely unknown. Lamenting that women's turnout initially and for some time lagged behind men's, as a general rule, has often obscured the considerable variation in women's turnout across time and space after suffrage. Understanding the causes and consequences of this variation can provide important insight into the nature and potential of women's engagement with electoral politics in this era. What might we expect of women's mobilization into the active electorate in the presidential elections following enfranchisement? 


\section{Expectations for Women's Turnout}

New female voters shared many characteristics with long-enfranchised men: socioeconomic status, race, religion, region, age, and immigrant status, to name a few. They differed from men in two specific ways: They were new (to the electorate) and they were women. These two characteristics were, of course, closely related. The condition of being female was the defining factor that excluded women from suffrage, ${ }^{12}$ and the Nineteenth Amendment expanded access to the franchise on the basis of sex alone. In other words, female voters in the I920s and I930s were new because they were women.

Both their newness and their gender were expected by both contemporaries and later scholars to have important consequences for how and with what impact women employed their new right. It is not surprising that the turnout of women, as new voters, lagged behind that of men. Voting has long been characterized as a learned behavior and an acquired habit; turnout in the past increases the probability of turnout in the future (see Gerber, Green, and Shachar 2003; Plutzer 2002). Those who have been systematically denied the opportunity to participate are likely disadvantaged in the future; experience, it is hypothesized, reinforces attachment to the political system and generates higher turnout across the life cycle (cf., Niemi, Stanley, and Evans I984). Contemporary activists expressed the concern that women's turnout was hampered by lack of experience (Gerould I925; Wells I929). At the same time, the experience of other newly enfranchised groups suggests that acquiring the habit of voting may not be that difficult; other new voters appear to have turned out at nearly equal rates and in much the same manner as those already in the electorate (Kleppner I982a; Niemi, Stanley, and Evans I984).

New female voters, however, confronted unique conditions as a result of their sex. As Andersen (1990, I96) writes, "viewing women as simply one instance of the class of 'newly enfranchised voters' is inadequate" because women were not only denied the vote, but had been taught to understand themselves as "by nature unsuited to politics" (italics original). Dominant (but evolving) social customs equated femininity with the private sphere of home, as opposed to the public world of politics (Kraditor I98I; Lane I959; see Chapter 2).

Thus, women entering the electorate in the I920s had been socialized during a period of widespread female disenfranchisement and

${ }^{12}$ For women of color and immigrant women, race and citizenship also were exclusion factors, both before and after the passage of the Nineteenth Amendment. 
norms against women's political engagement. Social scientists have long recognized that the "times" in which one is born and socialized shape attitudes and behavior throughout life. Critical events, such as national enfranchisement, can disrupt beliefs and transform behaviors. Yet, not everyone changes in response to new information, and the likelihood of changed attitudes and behaviors is not uniform; younger people appear more open to change whereas the attitudes of older people are more "crystalized" and thus resistant to alteration (e.g., Beck and Jennings I99I; Mannheim 1952; Stoker and Jennings 2008). For these reasons, we should not be surprised that attitudes about appropriate roles for women continued to discourage some women from voting in the years after I920 (Andersen I996; Baker I984). For example, nearly 8 percent of respondents (one-ninth of all female nonvoters) in Merriam and Gosnell's (I924) classic study of nonvoting in I920s Chicago gave "disbelief in women's voting" as a reason; another I percent cited "objections of husband" (see also Gosnell 1927). In an explicit test of the effect of generations (e.g., Mannheim I952), Firebaugh and Chen (1995) find that women who were older at the time of enfranchisement were less likely to turnout to vote throughout their lives (i.e., to change their behavior) than women who were younger in 1920 , or who were born after the ratification of the Nineteenth Amendment (cf. Beckwith I986).

Thus women's turnout was believed to be hampered by both their newness and their gender. And indeed, that women's turnout after suffrage lagged that of men is not in dispute. Because female turnout was not observed directly in most states, we have very few available indicators of turnout by sex. Nonetheless, to our knowledge, every known instance of available US data reveals a lower rate of turnout or registration among women as compared to men in the first elections in which women were eligible to vote (Arneson 1925; Berman 1993; Gamm 1986; Goldstein I984; Lebsock 1993; Pollock 1939; Sumner 1909; see Chapter 3). In other nations, where data on the sex of voters are available, women consistently turn out at lower rates than men immediately after suffrage (Duverger 1955; Tingsten 1937). Postwar survey work indicates that women's participation, although increasing over time, continued to lag that of men from the advent of survey research in the late I940s and I950s through the I970s (Berelson, Lazarsfeld, and McPhee I954; Campbell et al. I960; CAWP 20I4; Wolfinger and Rosenstone I980).

The rationale for and evidence of women's lower turnout, relative to that of men, is overwhelming. We are thus confident in treating women's lower rate of turnout as an assumption of this research, rather than a 
hypothesis to be tested. As we detail in Chapter 4 , the noncontroversial assumption that male turnout exceeds female turnout makes it possible for us to estimate women's turnout and vote choice with available aggregate data. However, it is important to emphasize that we assume only that male turnout exceeds female turnout; we do not assume anything about the size of the turnout gender gap. The few available studies reveal considerable variation in the level of female turnout and the size of the sex differential both within the United States and within and between other nation states (Burnham I980; Duverger I955; Goldstein I984; Niemi and Weisberg 1984; Tingsten 1937). The circumstances in which women were eligible to vote were clearly consequential. Thus, our analysis focuses on understanding variation in women's turnout at different times and in different places.

\section{Explaining Variation in the Mobilization of Women}

Although most accounts share the assumption that women entered the electorate as less politically experienced and engaged than men, the implications of this lack of experience and engagement on variation in turnout are ambiguous. As inexperienced voters, women may have been particularly susceptible to political cues and stimuli. Alternatively, women's isolation from politics may have made them resistant to traditional channels of influence and affect. Or, perhaps women's experience with and exposure to politics prior to suffrage resulted in responsiveness to political context similar to that of long-enfranchised men. We consider the possibilities in turn.

More Responsive to Context. A dominant characterization - both at the time and among many later scholars - is that newly enfranchised women were politically disengaged, uninterested, and inattentive (see Chapter 2). Even if we do not share contemporaries' expectations that women were inherently (i.e., by their very nature) less interested in politics, socialization and social norms during the period, as well as the experience of disenfranchisement, likely gave women less opportunity to learn about and develop an interest in politics.

As so understood, women shared fundamental characteristics with other low-propensity, or - to use terms long popular in political science "peripheral" voters. Peripheral voters are less engaged - both in terms of interest and activity - in political affairs than "core" voters. Core voters' interest in and attention to politics produces reliable electoral participation; the default behavior for core voters is turning out to vote. Although an unusual circumstance may keep core voters from the ballot box from 
time to time, those cases are the exception rather than the rule. Peripheral voters, on the other hand, pay little attention to and have little interest in, political affairs. As a result, their default behavior is nonvoting; unless given a strong reason to be active, peripheral voters tend to abstain from participating in elections (see Campbell I960, I964; Glaser 1962; Kaufmann, Petrocik, and Shaw 2008; Kleppner I982a).

As this discussion suggests, context - both across place and over time - is especially important for peripheral voters whose baseline propensity to vote is low. Core voters participate regardless of the circumstances. Peripheral voters require strong stimuli to overcome their basic disinclination to political activity. For example, close elections have long been identified as a spur to turnout (cf. Campbell et al. I960; Holbrook and Van Dunk 1993; Patterson and Caldeira 1983). Close competition is consequential for a number of reasons: It induces parties and candidates to expend greater effort on voter mobilization, encourages heightened press coverage, generates excitement and greater interest in the election, and increases the perceived value of any one vote (see Aldrich 1993; Rosenstone and Hansen 1993). The mobilization efforts associated with close competition have particularly strong effects on low-propensity voters (Arceneaux and Nickerson 2009; Hillygus 2005); while high-propensity core voters are already at, or near, their limits for mobilization, many peripheral voters remain available for mobilization.

Similarly, campaigns that involve highly salient issues with widespread interest and appeal and/or particularly charismatic or compelling candidates bring peripheral voters to the polls (Kaufmann, Petrocik, and Shaw 2008). The expectation that less politically engaged voters, such as women, are particularly affected by the nature of the campaign or candidate, or the closeness of the election, has a long history. For example, Glaser $(1962,38)$ writes, "when the glamour of campaigns and public concern vary, women, the young, and the lower class will fluctuate more in turnout than will men" (emphasis ours).

A similar logic leads us to expect barriers to voting to weigh particularly heavy on those already disinclined to turnout to vote. In particular, stringent legal requirements for voting are known to discourage participation (Patterson and Caldeira 1983; Powell 1986; Rosenstone and Hansen I993; Wolfinger and Rosenstone I980). Requirements that citizens register long before campaigns have made elections salient, pass literacy or citizenship tests, or pay a poll tax all add to the real and perceived costs of voting. For voters already disinclined to participate, the effort demanded by bureaucratic hoops may be a price they are unwilling to pay. Many 
of the major Progressive Era reforms, particularly the Australian ballot, were in widespread use by the time women entered the electorate. Yet, states and localities varied considerably in the types and stringency of the provisions they employed (Keyssar 2000). If women are rightly understood as peripheral voters, we would expect that women's turnout was especially responsive to variation across locales in the legal costs associated with voting. Black women were particularly singled out for oppressive implementation of the poll tax and other registration requirements, surely dampening their turnout (Lebsock I993). Some observers reported that Southern poll taxes also bore heavily on white women, perhaps to a greater degree than they did on poor white men or even African Americans (Bunche 1973; Wilkerson-Freeman 2002). Further evidence of the perception that the poll tax suppressed women's votes can be found in the considerable activism for poll tax reform by women's organizations in the decades following suffrage (Ogden I958; Scott I970; Tyler 1996).

There is some evidence that new female voters indeed behaved as peripheral voters in their turnout behavior. Within other countries, where turnout was generally low, male-female turnout differences after suffrage were relatively large. Where turnout rates increased, the gap between male and female turnout narrowed, sometimes considerably (Tingsten I937). Thus whatever encouraged male turnout appears to have had an even greater effect on female participation. In the United States, Kleppner (I982b) finds the closeness of the election to have a particularly strong stimulating effect on the turnout of new female voters. Thus, the expected lower levels of political interest and attentiveness among women may have resulted in turnout behavior that is more responsive to contextual shifts than men's: More depressed by barriers to voting and more stimulated by incentives.

Less Responsive to Context. Alternatively, new female voters may have been less responsive to context than were men. Some would argue that women were strongly disinclined to any political activity during this period. It was not simply that women were not well socialized into politics, but that they were strongly socialized into a nonpolitical role (Stucker 1976). As we discuss in Chapter 2, during the nineteenth and into the twentieth century, dominant conceptions of a woman's role clearly assumed she belonged within the confines of the home, where she was naturally suited to the responsibilities of the household, above all motherhood. Men and women were believed to occupy “separate spheres" with men's domain the public sphere of business and politics, and women's place the private sphere of home and family (DuBois I998; Kerber 1988). 
As a result, women's reluctance to challenge dominant norms may not have been overcome by any contextual stimuli; many women may simply have been unwilling to vote and no external conditions could convince them otherwise. For example, mobilization efforts may have little or no impact on those with the lowest propensity to vote because their disinclination to political activity is so strong that no outreach or stimulation can overcome it; only among intermediate-propensity voters (those with at least some inclination to political engagement) can mobilization efforts spur turnout (Matland and Murray 20I 2; Niven 2004, 200I). ${ }^{13}$ Women's presumed lack of interest also may have led them to pay less attention to or gather less political information, insulating them from contextual effects. All of these factors point to women's turnout being less responsive to the political context than was men's.

Equally Responsive to Context. Finally, perhaps the turnout of newly enfranchised women responded to their political context in much the same manner as men's did and thus, the size of the turnout gender gap was not systematically related to the political context. Political parties had an incentive to mobilize women as well as men, and as we discuss in the empirical chapters, there is good evidence that both sought to reach out to new female voters. Despite being characterized as apolitical, women did not arrive at polling places in 1920 completely devoid of political information or experience (see Cott 1990). Women engaged in various non-electoral forms of participation prior to their enfranchisement (Clemens 1997). Women's activism had both facilitated and benefited from an expanded definition of the political that encompassed issues about which women were expected to have special expertise, such as social reform, perhaps increasing female interest in politics (Baker 1984). Although political intensity and participation were declining by 1920 , most voting-age women nonetheless had been socialized in a period characterized by strong partisanship, highly salient and intense political debates, and widespread political participation (Burnham I965). This socialization may have facilitated the assimilation of women into their new political role. As a result, women may have responded as men did to changes in the political context.

In Chapters 5 through 8 , we evaluate each of these competing perspectives on women's turnout with the particular goal of understanding how

I3 As Arceneaux and Nickerson (2009) point out, much of the research finding no mobilization effect among the lowest propensity voters examines low salience local and state legislative races. They find that in more salient elections (such as the presidential elections examined here), mobilization efforts do impact even very-low-propensity voters. 
specific institutional and political features of the various states encouraged or discouraged the incorporation of women into the electorate. Did context have a greater impact on the turnout of women, as we would expect of a politically uninterested and inattentive group? Or were women so uninterested in and inattentive to politics that even the most politically stimulating contexts could not overcome their disinclination to turnout? Alternatively, did previous political experience and interest make newly enfranchised women as responsive to their context as long-enfranchised men? The answers to these questions, we find, emphasize the contingent and complex nature of women's incorporation into the electorate - where women were first eligible to cast ballots had important consequences for whether they did so.

\section{The Vote Choice of New Female Voters}

Generations of students and scholars have received a conventional and unremarkable account of the extension of suffrage. As early as I946, historian Mary Beard (6I-62) complained that "textbooks on government" (she singled out political science luminary V. O. Key in particular) "pay little or no attention to what women have done with the vote, to their political agitation, to their ideas of government.” Modern college-level American politics textbooks usually include the story of the women's suffrage movement and the ultimate success of the Nineteenth Amendment in their coverage of the extension (and retraction) of voting rights over time. In most cases, however, the story ends there; women won the right to vote, and then female voters disappear from discussion until the discovery of the gender gap in the I980s. As this timeline suggests, the inattention to women's electoral behavior after suffrage can be attributed to the prevailing understanding that women failed to emerge as a distinct and influential voting bloc after suffrage. For example, in their American politics textbook We the People, Ginsberg, Lowi, and Weir $(2009,298)$ conclude that "Although proponents of women's suffrage had expected women to make a distinctive impact on politics as soon as they won the vote, not until the I980s did voting patterns reveal a clear difference between male and female votes."

The failure of a women's voting bloc to emerge has been traditionally attributed to the widespread belief that women voted as their husbands and thus only replicated the male vote (see Alpern and Baum I985; Flanagan I995). The expectation that women would defer to their husbands and simply "double the existing vote" was pervasive even before 
the Nineteenth Amendment was ratified (McConnaughy 20I3, II). According to a I9I6 New York Times article,

The theory of the woman suffragists that, when accorded the right to vote, the women will vote independently of the men and cast their ballots according to their own convictions is not borne out by the returns from Illinois, where the votes of the women are counted separately. The women of that State voted squarely with the men on the main issue. Their voting nearly doubled the cost of the election and greatly increased the labors of the poll clerks, but the only way it affected the result was to make the Republican majority in Illinois larger than it would have been ... The lesson of Illinois is, therefore, that woman suffrage tends to increase the number of voters without affecting the result of the voting. ${ }^{\text {I4 }}$

As soon as women began exiting polling places nationwide, observers declared the expectation confirmed: "American women vote as their husbands, brothers, or fathers indicate," claimed journalist Charles Edward Russell (1924, 729). "Most of the women I know ... vote as their husbands vote," echoed writer Katharine Fullerton Gerould (I925, 450). In his popular treatise on American life in the I920s, Only Yesterday, journalist Frederick Lew Allen (I93 I, 95-96) described the "American woman:" "She won the suffrage in I920. She seemed, it is true, to be very little interested in it once she had it; she voted, but mostly as the unregenerate men about her did." Pioneering pollster George Gallup claimed in I940: "How will [women] vote on election day? Just as exactly as they were told the night before" (quoted in Berinksy 2006, 506). Histories of the period soon followed suit. For example, citing examples from journalists and political activists, historian William H. Chafe (I972, 3I) writes that "observers noted the same tendency of women to defer to men when it came to politics."

The idea that women took political direction from their husbands also characterizes many of the original, influential studies of American voting behavior. The Columbia scholars, describing data showing that, among married respondents, a larger percentage of women than men report that they "would go to a family member to discuss a political question" and "discussed politics with a family member," conclude (Berelson, Lazarsfeld, and McPhee 1954, I02): "The men discuss politics with their wives - that is, they tell them - but they do not particularly respect them. On the side of the wives there is trust; on the side of the husbands, there is the need to reply or guide" (emphasis original). It is not clear on what

${ }_{14}$ “The Illinois Women Voters." The New York Times, November 8, I9I6, p. I2. See also:

"The Women Who Voted." The New York Times, November I0, I9I6, p. I 2. 
evidentiary basis Berelson and his colleagues infer this set of attitudes or behaviors to explain the observed discussion patterns, other than the received conventional wisdom about the dependence of women on their husbands for political information and preferences.

Emphasizing women's reported lower levels of political efficacy, the authors of The American Voter likewise describe most (although not all) women as strongly influenced by their husbands (Campbell et al. I960, 492): "The wife who votes but otherwise pays little attention to politics tends to leave not only the sifting of information up to her husband but abides by his ultimate decision about the direction of the vote as well." (Ladd [I997, I I 8] notes that "The stereotyping achieved in this 'classic' account has rarely been equaled and never surpassed.”) In his influential paper, "The Nature of Belief Systems in Mass Publics," Converse (I964, 233) concludes that due to women's lesser sophistication, knowledge, and interest, "The wife is very likely to follow her husband's opinions, however imperfectly she may have absorbed their justifications at a more complex level."

Students of American elections rarely asked women or men directly about the reasons for the similarity of the votes of husbands and wives, but available comparative work provides some support for the assumption of dependence on the husband's expertise. Duverger $(1955,49)$, in his UNESCO report, The Political Role of Women, describes the results of a 1953 French survey in which

Nearly a third of the women questioned state that they voted in the same way as their husbands primarily because they were not interested in politics themselves and preferred to rely on their husbands' judgment. No man gave such a reply. One-fifth of the women questioned said that they wanted 'to avoid arguments', but only one man gave this answer. (italics in original)

It is presumably on this basis that Duverger (1955, I 29) later concludes

But, while women have, legally, ceased to be minors, they still have the mentality of minors in many fields and, particularly in politics, they usually accept paternalism on the part of men. The man - husband, fiancé, lover or myth - is the mediator between them and the political world.

Not everyone followed the "vote like husbands" script. Political scientist Charles Merriam wrote in I929 (I 54-I 55 ):

... the general testimony has been that votes are not primarily determined by sex lines, but by other social considerations. This cannot be taken to mean that women follow the lead of men, for in many instances the contrary is true, and the woman may persuade or cajole or intimidate the man. 
Yet even many of those who allow that women of the era may have exercised independence of thought and judgment still expect that women voted the same as men did. The reason was not women's deference to men but that women, like men, voted in ways consistent with relevant group characteristics such as socioeconomic status, race, or religion (e.g., Chafe 1972; Goldstein 1984). As no less an authority on women and politics than Eleanor Roosevelt wrote in I940 (45), "I think it is fairly obvious that women have voted on most questions as individuals and not as a group, in much the same way that men do, and that they are influenced by their environment and their experience and background, just as men are." Given the fairly equal distribution of women across demographic groups, the expected outcome is still little or no difference in partisan mobilization, and thus electoral impact, associated with the entrance of women into the electorate.

Although the "voted like their husbands" conventional wisdom is popular, a closer read of previous research reveals a number of expectations for divergent vote choice among men and women. Many assert that Republicans held an advantage among women in the first elections in which women were eligible to vote, for example (see Alpern and Baum 1985; Brown I99I; Goldstein I984; Willey and Rice 1924). Women were often expected to be stronger supporters of Progressive causes and candidates (e.g., Ogburn and Goltra r9r9). The issues of Prohibition and religion were believed to have particularly stimulated female mobilization - both for and against Democrat Al Smith - in I928 (Andersen I996; Burner I986; Burnham I980; Matthews I992; Sundquist I983). Others have suggested women - whose limited experience with the ballot made them uniquely available for both mobilization and conversion - played a distinctive role in New Deal realignment (Andersen 1979; Gamm 1986). From these various accounts it is clear that there are a number of open questions about women's mobilization and incorporation into the partisan electorate. The empirical chapters describe and evaluate these election-specific claims in detail. In the section that follows here, we consider general expectations for female voters' patterns of partisan support overall.

\section{Expectations for the Partisan Mobilization of Women}

Accounts of women's suffrage include both claims that women voted exactly like men and claims that women were distinctive in their vote choice. Research on vote choice and elections more generally also supports various expectations for the partisan mobilization of women, 
depending in large part on our assumptions about both newly enfranchised women and the contexts in which they first cast their ballots. We consider the competing claims below and evaluate them in Chapters 5 through 8 .

Women as Swing Voters. There are a number of reasons to expect female voters were particularly susceptible to election-specific partisan swings. As we have noted, women were widely assumed to be politically uninterested, inattentive, and disengaged, the classic description of so-called peripheral voters. In addition to being less likely to turn out to vote, peripheral voters are less loyal partisans and more swayed by election-specific factors than long-term allegiances. The same factors salience, competition, unusually appealing candidates, compelling issues that are expected to stimulate turnout among peripheral voters also drive their vote choice when they do participate. Because peripheral voters' partisan attachments are less grounded in experience, information, and reasoning, they are more susceptible to the election-specific messages that favor one candidate over the other (Kaufmann, Petrocik, and Shaw 2008; Miller and Shanks i996).

Other characteristics of new female voters also point to swing voter behavior. Women's lack of experience meant missed opportunities for reinforcing commitment to the electoral system and to a particular partisan preference. Converse's ( I969, I976) classic statement on partisan stability emphasizes the importance of reinforcement via electoral participation for explaining the increasing stability of partisan identity over time, an expectation confirmed by later research (e.g., Jennings and Markus 1984; Stoker and Jennings 2008; see also McPhee and Ferguson 1962). Converse (I969) predicted that those enfranchised later in life would have particular weak partisan attachments (and turnout), not only because of the lesser time for reinforcement through electoral participation, but also because of the missed opportunity for the establishment of political affiliations during the early life socialization process.

There are gender-specific rationales for the expectation of less loyalty to the two major parties as well. Contemporaries often described women as more committed to ideals than to party (Barnard I928c; Monoson I990; Rogers 1930). The Progressive movement denounced political parties as corrupt and inefficient, so to the extent women were Progressive minded, they were expected to shun traditional parties (see Andersen I990). Finally, women's lack of influence in the parties and the selection of nominees led some to argue that neither parties' candidates represented 
the interests of women, discouraging loyalty to either party (Fisher 1947; Flanagan I995; Martin 1925).

Thus, we might expect newly enfranchised women to be, on average, less loyal partisans and more susceptible to election year swings than established voters (Lemons I973; Rusk I974). Evidence in support of this hypothesis in the case of new voters, including women, has been mixed (e.g., Cain, Kiewiet, and Uhlaner I99I; Claggett I980; Niemi, Stanley, and Evans I984; Niemi et al. I985; Wong 2000). Claggett (I982) considers the case of female enfranchisement explicitly, noting that Converse's framework would predict weak partisan ties among new women voters, which would in turn lead to greater electoral instability following suffrage extension. He finds no such surge in electoral instability after 1920.

Women Mobilized by Particular Parties. On the other hand, some contemporary observers and later scholars concluded or expected that new female voters gave particular support to one or another of the parties, what we term the "particular partisanship hypothesis." Specifically, a number of accounts suggest women's suffrage benefited the Republican Party, at least initially (e.g., Bagby I962; Brown I99I; Burner I986; Gould 2003; Lemons 1973; McCoy 1971; Pateman 1994; Smith 1980; Willey and Rice 1924; see Chapter 5). The most cited evidence in support of this expectation is the fact that in I9I6, the Democratic incumbent received 9. I million votes to his Republican challenger's 8.5 million. In I920, following the passage of the Nineteenth Amendment, the Democratic candidate again received 9.I million votes, while the number of votes secured by the Republican almost doubled to I6.I million votes (Brown I99I).

Why might the first female voters favor the Republican Party? The Republican Party was the major party most associated with Progressivism during the first elections in which women were eligible to vote, and it was a Republican Congress that passed the Nineteenth Amendment. Moreover, there is some evidence that Republicans more directly and overtly appealed to women voters, while Democrats chose not to depend on sex-specific appeals (Barnard I928a, I928b; Jensen I98I). Suffrage leaders themselves were overwhelmingly middle-class Protestants, characteristics associated with Republican identification in the mass electorate. Many expected that the first women to take advantage of their new right likely shared those characteristics, and attribute the Republican bias among women voters to which women voted, rather than to women as a whole (Rymph 2006).

As this discussion suggests, an expectation that women favored the goals and ideals of the Progressive movement underpins many 
expectations for particular partisanship. Women (and women's organizations) had been active and prominent participants in the Progressive movement, and Progressive ideals, particularly moral reform, were consistent with the qualities associated with women during the nineteenth and early twentieth century (Baker I984; Evans I989; see Chapter 2). Indeed, concern that women would use the vote to achieve Progressive goals, particularly prohibition, galvanized a number of active opponents to women's suffrage, most notably the liquor industry (Flexner I959; McDonagh and Price 1985). Many expected women's votes to be particularly influenced by Progressive issues such as prostitution, gambling, poverty relief, child labor, workplace health and safety, good government, and especially prohibition (Allen I930; Flexner I959; McCormick I928; Ogburn and Goltra I9I9; O’Neill I97I; Rice and Willey I924; Russell I924; Tarbell I924; Toombs I929; Wells I929; Willey and Rice 1924). As we have suggested, in 1920 , the party most closely associated with Progressivism was the GOP. In 1924, however, recently enfranchised women had the option of casting a ballot for an actual Progressive Party candidate, Robert M. La Follette. Thus, we might expect women were more likely than men to cast their ballots for Republicans, or when available, for candidates associated with the Progressive cause.

Women Mobilized by Locally Dominant Parties. We also consider a third possibility - that the first female voters may have favored locally dominant parties. Harvey (I998) argues that long-established political parties had an advantage over new interest-based women's organizations in mobilizing female voters into electoral politics. Both parties and interest-based groups had experience with and expertise in mobilizing male voters, and thus both were responsible for bringing men to the polls. Women's groups, however, had little experience in voter mobilization and difficulty transitioning to that new role, and thus new women voters were mobilized almost exclusively by parties. As a result, Harvey (I998, I47) predicts that

... male registration and voting behavior during the I 920 should reflect not only the mobilization efforts of the two parties, but also the efforts of independent benefit-seeking organizations attempting to mobilize male votes for their own purposes. Conversely, women's registration and voting behavior would reflect only the efforts of the parties to mobilize their loyalties.

Thus, "holding the partisan strength of any area constant, we should see women registering and voting disproportionately with the local dominant party, relative to registering and voting men" (I998, I48). 
Other processes may have contributed to greater mobilization of women by the locally advantaged party. The period preceding 1920 was characterized by strong partisanship and widespread one-partyism (e.g., Burnham I98 Ia). Even when denied the right to vote, women would have been exposed to communities where in most cases one political party dominated in terms of loyalty among the mass electorate and control of political office. One-partyism likely shaped the consistency and strength of the political messages that women received (what we might describe as partisan socialization), influencing their sense of partisan identification and their vote choice once enfranchised (e.g., Beck and Jennings I99I; Mannheim 1952; Stoker and Jennings 2008).

Both men and women would have been exposed to these strong partisan messages, but women may have experienced more homogeneous and reinforcing partisan cues. During this period, men were more likely than women (particularly middle-class, white women) to work outside of the home or immediate neighborhood, thus exposing them to a greater diversity of partisan cues. Presented with conflicting messages, we might expect men to be less consistent in their vote choice (Berelson et al. 1954; Huckfeldt et al. I995). To the extent that women were less likely to work outside the home or neighborhood, the partisan cues women received may have been more uniform, resulting in more consistent and stable vote choice. For example, in his classic study of Jews in I950s Boston, Fuchs (1955) notes that Jewish women's interactions were far more circumscribed than were their husband's (most women rarely left their own ward), resulting in distinct political patterns: Men, exposed to the non-Jewish community, were more likely to defect from traditional Jewish patterns in vote choice than were women. Many women in the suffrage era may have experienced similarly homogeneous political environments in their homes and neighborhoods compared to the greater diversity of cues to which men may have been exposed. Such experience may have inculcated greater loyalty and responsiveness to the locally dominant political party. For these several reasons, then, we might expect the first female voters to be particularly likely to support the locally dominant party, what we term the "local party hypothesis."

Women Mobilized as Men Were. Finally, we might expect, as many have long concluded, that women's vote choice was, on the whole, indistinguishable from that of men. The justifications for such an expectation run in at least two directions. In one framing of this expectation, women are once again understood as politically uninterested and inexperienced. However, Campbell and his collaborators (I960, 492) argue 
that because women relied on their husbands for political information and other guidance, women's partisanship and vote choice was more stable than we might expect for a similarly inexperienced group: "Since the partisan decision [of women] is anchored not in these fragments [women's lesser political information] but in the fuller political understanding of the husband, it may have greater stability over a period of time than we would otherwise suspect." In other words, unlike most new voters, and unlike the typical uninterested and inattentive citizen, women had easy access to political knowledge and information via the men in their lives (husbands, fathers, sons). As a result, their political preferences were rooted in stronger attachments than is the case of most new or uninformed voters. The authors of The American Voter thus do not challenge the characterization of newly enfranchised women as inexperienced and uninterested, but they do provide a rationale for the popular "voted like their husbands" conclusion (e.g., Alpern and Baum I985; Gerould I925; Russell I924) grounded in established theories of partisanship and political knowledge.

A second - alternative or additional - way we might explain women's vote choice as similar to that of men emphasizes that women did not enter the electorate entirely devoid of political experience, interest, or opinion. As discussed in the preceding text and in detail in Chapter 2, although women were denied the right to vote, they were not absent from political activity and activism prior to I920 (Clemens I997; Cott I990), experiences that would have exposed them to the same sorts of political knowledge and cues to which men were exposed. As we have noted, the heightened partisanship of the period likely made political information relatively easy to come by. Suffragists themselves, particularly those who put forward equality rather than difference arguments (see Chapter 2), had argued that women were fully capable of engaging in politics in just the same manner as men did (McConnaughy 20I3). While Campbell et al. (I960) expect that in shared households and communities, men influenced the vote choice of women, we note that men and women in shared households also likely shared ethnicity, race, nativity, class, religion, and a host of other politically relevant characteristics. To the extent that we expect such factors to predict male vote choice, we might expect them to have a similar impact on women, with the result of similar partisan mobilization patterns among men and women. As Goldstein (1984, I47) argues: "The mere fact that the men and women in an area voted similarly does not imply the either sex was dominated by the other. Members of both sexes acting independently of the other 
could easily arrive at the same solution of the voting calculus." Thus we might expect to see the first women who entered polling places mobilized by parties in much the same way men were.

In Chapters 5 through 8 we examine the evidence in support of each of these hypotheses. Were women "peripheral voters" - swinging from party to party in response to election-specific forces? Were female voters "particular partisans" - more likely to support specific parties, such as the Republicans or Progressives? Were female voters more loyal to the locally dominant party than were men? Or were women "normal" partisans, indistinguishable in their vote choice patterns from long-enfranchised men? As we will see, each of the five presidential elections between 1920 and 1936 provides a particular type of leverage for examining these questions.

\section{Evaluating the Contributions of Female Voters}

A full understanding of the electoral behavior of new female voters requires attention to both mobilization in general (turnout) and mobilization by and into particular political parties (vote choice). It is the combination of these forms of mobilization, particularly in comparison to the mobilization of long-enfranchised men, by which we can understand and evaluate the impact of women's suffrage on electoral politics immediately following enfranchisement.

What might we expect in terms of the impact of new female voters? As we have suggested, almost immediately after women exited the polling places in November I920, a conventional wisdom emerged that women's suffrage produced no impact: New female voters took up their right in only very limited numbers, and those who did cast ballots voted so similarly to men that the impact of female voters on American politics was virtually nonexistent. The often-unstated standard was a rather dramatic political change: Women suffrage would be judged to have an impact if and only if women voted in such numbers and so distinctively as to change election outcomes.

In one sense, this is not an unreasonable standard. Elections are contests for the selecting of political representatives, and influence over - or better yet, determination of - that choice is power indeed. Given their share of the population, women certainly had the potential to play such a pivotal role in election outcomes. Such an impact, however, requires women to turn out at levels nearing or even surpassing those of men, and/ or to cast their ballots for different candidates and parties to a significant 
and dramatic degree. Neither of those conditions strike us as likely during the period examined here. As we have detailed, we have every reason to expect women's turnout to lag behind that of men during this era (although we expect the size of the gap to vary considerably across time and place). Similarly, even without an expectation that women voted like their husbands, the fact that women were similarly distributed among socioeconomic, religious, and other politically relevant groups suggests that vote choice differences, while certainly possible and meaningful, are unlikely to be large. Since the dawn of modern survey research, the gap between the presidential vote choice of men and women has never exceeded I5 points ${ }^{15}$ - enough to influence election outcomes, but only in the context of considerable female turnout and/or a very close partisan divide between male voters. Although possible, on the whole, we do not expect to find that women changed the outcome of presidential contests at the state or national level in the first elections after suffrage.

Does this reality mean that women's suffrage did not matter? Changing the outcome of an election is not, we argue, the only way in which newly enfranchised women may have had an effect on elections and electoral politics. Indeed, a single-minded focus on that high standard has, we believe, obscured the many possible other ways in which women's presence affected elections. Instead of emphasizing who determines the outcome, we focus on who contributes to the outcome, and how, thus permitting us to observe the ways in which women's presence made elections different than they might otherwise have been. What did women contribute to the Republican landslide in 1920? What role did women play in the impressive showing of the Progressive Party in I924, or alternatively, the ability of the Republican Party to successfully stave off the Progressive challenge? Perhaps most importantly, what was the contribution of women to the shifting partisan alignments of the I928, I932, and 1936 elections? Did women, as many expected, play a significant role in dampening enthusiasm for Democrat (and Catholic) Al Smith in the Republican (and Protestant) Midwest? Did undermobilized immigrant (Catholic) women in the Northeast contribute to dramatic Democratic inroads there? Were undermobilized women responsible for large portions of the new voters who entered the active electorate during the New Deal realignment period? Were women more likely to convert from one party to another? What did women contribute to both stability

is Source: American National Election Studies. http://electionstudies.org/nesguide/2ndtable/ t9a_I_I.htm (Accessed May 2I, 20I3). 
and change in partisan alignments across this period? How might patterns of mobilization overall and by each party been different if women had remained disenfranchised?

We combine both forms of mobilization - turnout and vote choice to investigate the contribution of female voters to the global patterns of electoral stability and change in each presidential contest. We give particular attention to the transformative elections of I928, I932, and 1936 as the "System of I896" (Burnham I970, I98 Ia) unraveled, giving way to the New Deal realignment. By doing so, we offer a richer and more nuanced account of the impact of women's suffrage on American elections which takes into account the varied ways in which new female voters may have contributed to electoral patterns across this dramatic period in American political history.

\section{A Brief Preview}

Our research reveals that the behavior and impact of new female voters was both complex and contingent. Women's use of their new right was dependent - more so than men's - on context: Women's turnout was especially stimulated by a competitive political environment, and particularly dampened by restrictive voting laws throughout the period. As we have outlined, this responsiveness to context is consistent with what political science expects of a group that is characterized by a lower level of political engagement (peripheral voters), but not as completely disengaged from politics as many expected of women of the period. As a result, both the level of women's turnout and the size of the turnout gender gap varies considerably from state to state; as early as I920, we estimate women's turnout to exceed 55 percent in highly competitive Kentucky, while fewer than 5 percent of Virginian women turned out to vote in that same election. These findings challenge attempts to characterize women's political engagement as solely determined by their gender or inexperience. Where encouraged and motivated to do so, newly enfranchised women were capable of impressive levels of mobilization. Where women were enfranchised mattered more for women's turnout than the fact that they were women.

On the whole, we conclude that women did not cast ballots for dramatically different parties and candidates than did men. Yet the partisan mobilization of women did differ from that of men in particular places and at particular times. In the first presidential elections, we find that women are particularly mobilized by the locally dominant Republican Party in the Midwest, but are not more Republican than men nationwide, 
contrary to conventional accounts. In I924, we find women were as likely, or in a few places less likely, to cast Progressive votes than were men, again contrary to expectations that women were particularly inclined to support Progressives and/or fickle, inexperienced, and loosely tied to the major parties. This set of findings suggests women were initially mobilized by and loyal to the parties traditionally dominant in their state, consistent with the local party hypothesis, and contrary to the expectations of many that women were less dependable partisans.

We find that women were dramatically mobilized in 1928 , both for and against Smith, as many have long expected. Yet, contrary to the conventional wisdom, women were not unique in 1928; men also experienced a massive surge in turnout and shifts in vote choice in 1928 , equalling or exceeding that of women. Finally, as the New Deal realignment unfolded over the 1932 and 1936 elections, women and men were mobilized into the electorate in large numbers as Democrats. Although we cannot trace conversion and mobilization definitively, our estimates do provide insight into general patterns. We conclude that women were, as expected, more likely than men to defect to the Democratic Party (we observe this most clearly between I 928 and I932). However, given the larger number of men already in the active electorate, we also conclude that conversion likely played a larger role for men, and mobilization a larger role for women, in generating new Democratic votes. Despite the fact that the number of men participating in presidential elections was much larger, the combined impact of conversion and mobilization in our sample states nets about I. 5 million new Democratic female voters and I. 5 million new Democratic male voters. A mere sixteen years after the extension of the franchise, women's ballots made up an equal share of the gains that underpinned the new Democratic majority. Thus, our research both confirms some aspects of traditional or conventional accounts and challenges others.

\section{What Follows}

In the chapters that follow, we review the theoretical and historical background of American women as political actors prior to suffrage with the goal of informing our understanding of their electoral behavior after suffrage, as well as assess what previous scholarship has already told us about how women first used the vote. We describe the design of the research reported in this work, including the original data and innovative methodological approach used to estimate women's and men's turnout and vote choice in these five elections. We use those estimates to 
investigate a number of puzzles about the behavior and impact of female voters in the five presidential elections after suffrage, and conclude by summarizing our answers to the major questions raised and considering how the experience of the first female voters relates to the decades of female electoral participation that have followed.

We begin by placing our investigation into the behavior and impact of female voters after suffrage into a broader understanding of women and the vote in American history and American politics. In Chapter 2, we examine how conceptions of voting as an act of citizenship and about women as political actors in a democracy evolved over time in the United States. We briefly review the history of the struggle for voting rights for women, emphasizing how that battle shaped the expectations for women's contribution once the vote was won. We examine the other ways in which women affected politics, both before and after the ratification of the Nineteenth Amendment. Denied access to the dominant mode of mass politics in the nineteenth century - voter mobilization - women helped to invent new forms of political influence through social movements and interest group politics. In doing so, they helped shift the distinctions between public and private, both by helping to bring politics into arenas that had previously been considered beyond the reach of the state (particularly the home), and by bringing what were traditionally considered women's interests - care of children, social purity, food and other consumer goods - into the public realm. This process had important consequences for twentieth-century politics writ large, but also directly shaped the expectations for and experience of new female voters.

Interest in the electoral incorporation of half the population has inspired a number of efforts to gain insight into women's voting behavior after suffrage. In Chapter 3, we review what we know from available data and research. In some cases, scattered pieces of actual hard data on registration, turnout, party identification, and even vote choice are available by sex, either because the information was tabulated in that way or researchers have scoured archives for registration lists or voter rolls. In other cases, scholars have, with varying success, sought to estimate female voting behavior during this era, sometimes despite (or without awareness of) the hazards of relying on aggregate data. By detailing what we do know, with some confidence, about women's electoral behavior immediately following the extension of suffrage, we also identify the very real limits of that knowledge, and the need to expand upon our evidentiary basis to more fully evaluate women's electoral behavior and impact after suffrage. 
Some ninety years after the ratification of the Nineteenth Amendment, why don't we know more about the behavior and impact of female voters? As scholars have long lamented, "male and female ballots had been fatally co-mingled" (Alpern and Baum I985, 44), and reliable voter surveys of the period are more or less nonexistent. Chapter 4 introduces our approach to this challenge. As this chapter focuses on data and methodological details, some readers may prefer to skip to the substantive findings reported in the chapters that follow. We first describe how and why we constructed our ten state sample, discuss the election returns and census data we gathered at various levels of aggregation, and compare our sample to the broader United States. We discuss the politically relevant state-level variation captured by our sample, with particular attention to region, party competition, and the legal obstacles to voting. We review, in broad strokes, the evolution of methods of ecological inference since Robinson (I950) identified the ecological fallacy. We describe the Bayesian approach to ecological inference employed in this research to estimate women's turnout and vote choice at the state level. We consider the problems and possibilities inherent in ecological inference in the case of gender, specifically the low variation in proportion of women - the population of interest - across geographic observations. We verify the accuracy of our estimates by reference to available "true" data from Illinois where male and female ballots were counted and reported separately in I9I 6 and I920. An appendix provides detailed information about statistical programming choices and evaluation of convergence and other properties of the estimator.

The heart of our empirical analysis is reported in Chapters 5 through 8 , in which we explore the ways in which women did (and did not) turn out to use their new right, for which candidates and parties, and to what effect on American elections. In Chapter 5 we examine the election of I920, heralded as the "return to normalcy" and at minimum, a return to Republican ascendancy after World War I and the Wilson interlude. The election of 1924 , featuring a relatively successful third-party candidate who represented the cause of Progressivism, long associated with the activism and interests of women, is the focus of Chapter 6. In Chapter 7, we take on the high-salience election of 1928 , in which both contemporary observers and later scholars expected the historic candidacy of Catholic Al Smith and the central issues - religion and Prohibition - to generate unprecedented interest and mobilization among women on both sides of these issues. Finally, in Chapter 8 we turn to the transformative New Deal elections of 1932 and 1936, when recently enfranchised 
female voters were particularly available for both conversion (because they lacked repeated electoral experience to reinforce partisan loyalties) and mobilization (because so many women had not yet entered the polling place) into the emerging Democratic majority.

In Chapter 9 we focus on what our findings as a whole tell us about key long-standing questions about the incorporation of women into the American electorate. Using contemporary survey data, we place the first female voters within the broader context of the nearly roo years of women's electoral participation that has followed. Finally, we return to the central question of this research: Did women's votes count?

The title of this book - Counting Women's Ballots - is meant to evoke both the substantive questions and methodological challenges at the heart of this research. The empirical impossibility of counting the ballots of newly enfranchised women separate from those of long-enfranchised men has confounded scholars for almost roo years. Ballots are not distinguished by the sex of the people who cast them, and the solution employed by later scholars - public opinion polls - are unavailable or unreliable during this era. New advances in ecological inference allow us to "count" women's ballots - that is, to produce unique and reliable estimates of women's turnout and vote choice - for more locales and elections than possible with previous methods and data.

These estimates permit us to gain insight into the central theoretical and empirical puzzles driving this research: Did women's ballots "count" in a substantive sense? Specifically, what did women contribute to electoral stability and change during this transformative era? Using our new evidence to provide greater insight into the electoral behavior and impact of women after suffrage is the goal of this book, and the task to which we now turn. 